\title{
市街化農地における農業用ビニ ルハウスの用途外利用に関する 研究
}

\section{A STUDY ON ALTERNATIVE USAGE OF GREENHOUSE IN RURAL-URBAN FRINGE}

\author{
中島亮二 \\ 棒田 恵

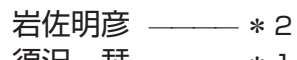 \\ キーワード : \\ ビニルハウス, 用途外利用, セルフビルド, 市街化農地
}

Keywords:

Greenhouse, Alternative usage, Self-build, Rural-urban fringe

$\begin{array}{ll}\text { Ryoji NAKASHIMA —— } * 1 & \text { Akihiko IWASA }-* 3 \\ \text { Satoshi BODA } & * 2 \\ * 3 & \text { Shiori SUZAWA }-11\end{array}$

This study aims to explore the actual situation of rural-urban fringe through on-site survey of alternative greenhouses in Niigata city. The alternative greenhouses are utilized not for agricultural use but for living, entertaining use and so on. Changing of a form and use of the alternative greenhouses are influenced by pragmatic way for a resident such as self-repairing and availability of materials.

As a result, the study reveals that the form of the alternative greenhouses and the surrounding environment are mutually related. Furthermore the alternative greenhouses play a key role in adjusting the resident's demands between urban and rural area.

\section{1. 研究背景・目的}

農業用ビニルハウス（以下、農業用VH）は、1950年頃から全国 各地に普及し、育苗や栽培用途で用いられてきた。農業用VH は単 純な構造で、設置や改造が容易であり、本来の栽培用途に限らず、 利用者が必要な空間を自作する際に利用されている。特に、スプロー ル化が顕著で住宅地が混在する市街化農地においては、商業や居住 に関連する用途で利用されるビニルハウス（以下、用途外 VH）が存 在し、市街化農地におけるひとつの特徴となっている（写真 1,2 )。 農地周辺の小空間に関寸る既往研究は、作物の貯蔵や乾燥に供する 小屋を対象とし、その建築的特徴および生業の変遷との関係 ${ }^{1}{ }^{1)}$ や その成立と変遷 ${ }^{2)}$ を明らかにしたものがある。しかし、戦後急速 に普及したVHを対象とした研究はなく、用途外 VH が市街化農地に おける特徴的な空間のひとつであるにも関わらず、その実態は明ら かになっていない。また、用途外 VH は個人で容易に設置でき、地 域において生活上不足するものを個人レベルで補えることから、市 街化農地の状況やそこでのニーズを敏感に反映していることが期待 できる。本研究では、新潟市の市街化農地の用途外 VHを対象として、 用途や立地、形態からその転用の実態を明らかにすることで、市街 化農地における用途外 VH の役割と可能性を考察する。

\section{2. 調査概要}

新潟市の市街化農地において目視調查を実施し、用途外利用が確 認できた用途外 VH の撮影と観察記録注 1) を行った（図 1)。調查は 2013 年 9 月 16 日から 10 月 31 日に 6 回に分けて実施した。得られた 115 事例に対して【用途】、立地】、形態】の観点注 2) から分析を行い、 導出した $5 つ$ の形態指標を基に、用途外 VH の特徴を明らかにした。

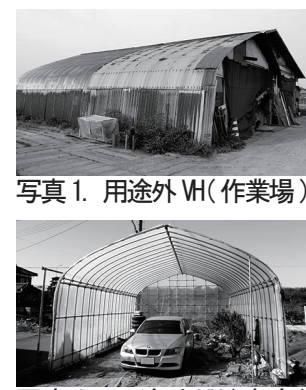

写真 2. 用途外 VH( 車庫)

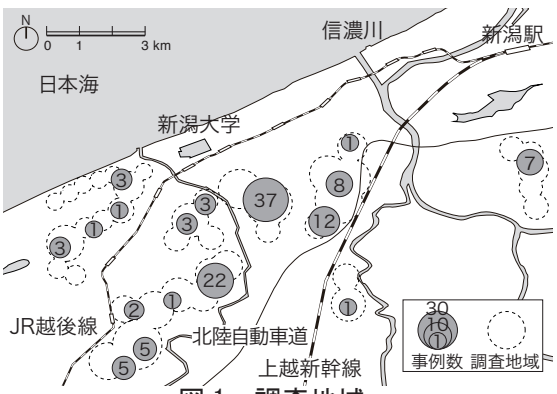

図1. 調査地域

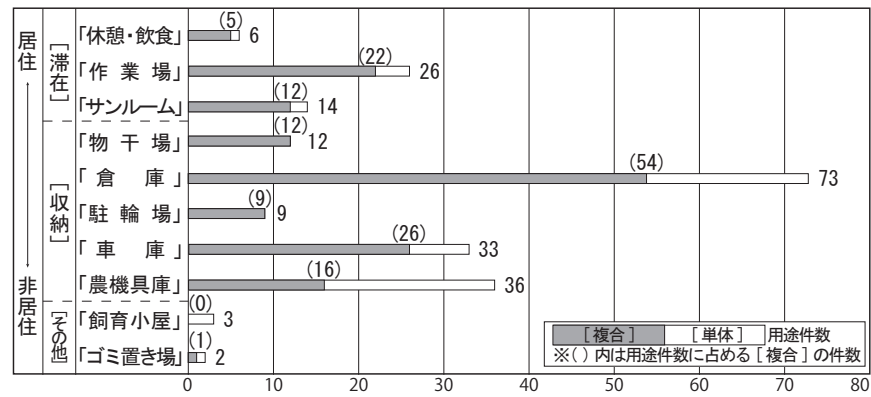

図 2. 用途毎の件数

表 1. 立地の内訳

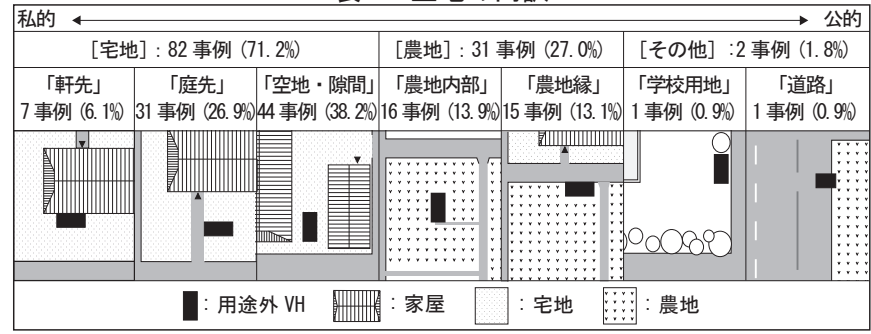

1 新潟大学大学院自然科学研究科 博士前期課程

（９50-2181 新潟市西区五十嵐 2 の町 8050)

法政大学デザイン工学部建築学科 教授・博士 (工学)

職業能力開発総合大学校能力開発院 特任助教・博士 (工学)
Graduate Student, Graduate School of Science and Technology, Niigata Univ.

Prof., Dept. of Arch., Fac. of Engineering and Design, Hosei Univ., Dr. Eng. Assistant Prof., Faculty of Human Resources Development, Polytechnic Univ. of Japan, Dr. Eng. 


\section{3.【用途】/住居の補完、市街地と農地の関係を調節}

用途外 VH にみられる育苗・栽培以外の用途は 10 種類で「居住一 非居住」の観点から見ると、大きく [滞在 ] と [収納 ]に分けられる。 そのうち [ 滞在 ] に用いられる事例では、一般に開放し飲食の提供 やイベントの開催に活用する事例や、騒音や粉塵が出る木工作業場 といった事例があり、用途外 VH は住居内に持ち込むことが忌避さ れ、住居では充足できない機能を補完する場として利用されている と推察できる。それに加えて、「作業場」や「農機具庫」などの営 農に関する用途も見られる。また、115 事例のうち、58 事例 (50.4\%) が複数の用途を持ち、全事例の用途数は延心゙ 214 件となった。これ ら複数の用途を持つ [複合] 事例を見ると、「倉庫」が 54 件 (25.2\%) で最も多く、次いで「車庫」が 26 件 (12.1\%) であった（図 2)。[収 納］用途は他の用途と併設されることが多く、用途外 VH は汎用性 の高い空間として、複数の用途で兼用されていると言える。以上か ら、用途外 VH は利用者の必要に応じた空間を簡便に実現するため に用いられ、住居を補完する用途や営農に関する用途を担い市街地 と農地の関係を調節する役割を果たしていると考えられる。

\section{4.【立地】/生活空間との距離を保って設置}

用途外 VH の立地は 7 種類あり、「私的一公的」の観点から見ると、 大きく [ 宅地］と［農地］に分けられる。用途外VH は [ 宅地］に 82 事例 $(71.2 \%)$ が設置されており、主に家屋付近で利用されてい る（表 1)。[宅地］内でさらに詳しく見ると、「空地・隙間」の 44 事例 $(38.2 \%)$ が最も多く、次いで「庭先」が 31 事例 (26.9\%) であっ た。用途外VH は、主に家屋付近に設置される一方で、生活空間と の距離を保っている。これは、用途外 VHによって付随される用途 の多くが、住居内で忌避されるものであることが一因と考えられる。

\section{5.【形態】 $/ 5$ つの形態的特徵}

用途外 VH は、規格化された部材を配列して架構を構成するため、 規模に関わる「高さ」、間口幅」、「奥行き」のうち、「高さ」と「間 口幅」は規格上の相関があり、「高さ」と「奥行き」でその規模を 比較することができる。「高さ」に関しては、110 事例 (95.7\%) が 内部で人が直立可能であった。「奥行き」では、全長が $100 \mathrm{~m}$ を超え ることもある農業用 VH と比心゙、 89 事例 $(77.4 \%)$ が $12 \mathrm{~m}$ 未満と小規 模であった（図 3)。用途外 VH は奥行きを調節することで、狭小な 敷地に設置され、内部で人が活動できる規模で利用されている。

以下では、VH の構成要素 (図 4) から、 5 つの形態的特徵を述べる。

\section{5-1. 改造のされ方 / 内部収容物の保護}

用途外 VH の改造のされ方を、[フレーム］、[ 付加物］、[カバー］ の形状がどのように変更されているかによって検証した。［フレー ム］の「断面形状」に関しては [ フレーム ] に手を加えない〈標準型〉 が 91 事例 (79.1\%) と最も多い（表 2)。[ 付加物 ] では廃材や不要 物の[流用]が 7 件、素材を加工した〔造作]が 8 件あった（表 3、4）。 用途外 VH の空間を決定寸る大きな要因であるカバー素材が変更さ れた 58 事例のうち軟質な素材が 44 事例 (75.9\%) と多く見られるが、 硬質な素材が 14 事例 (24.1\%) あり、内部収容物の保護が必要な場 合には特に手が加えられていると考えられる（表 5)。

5-2. 既存の活かし方 / 既存地面の保持、周囲にある資材の活用

用途外 VH の既存の活かし方を、[ベース］に関して資材の使用

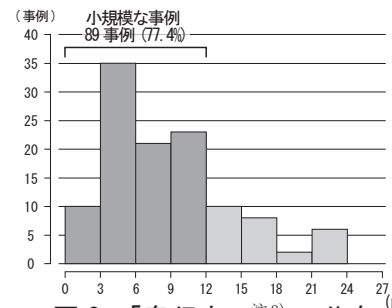

表 2.「断面形状」の内訳

図 3.「奥行き」注3) の分布
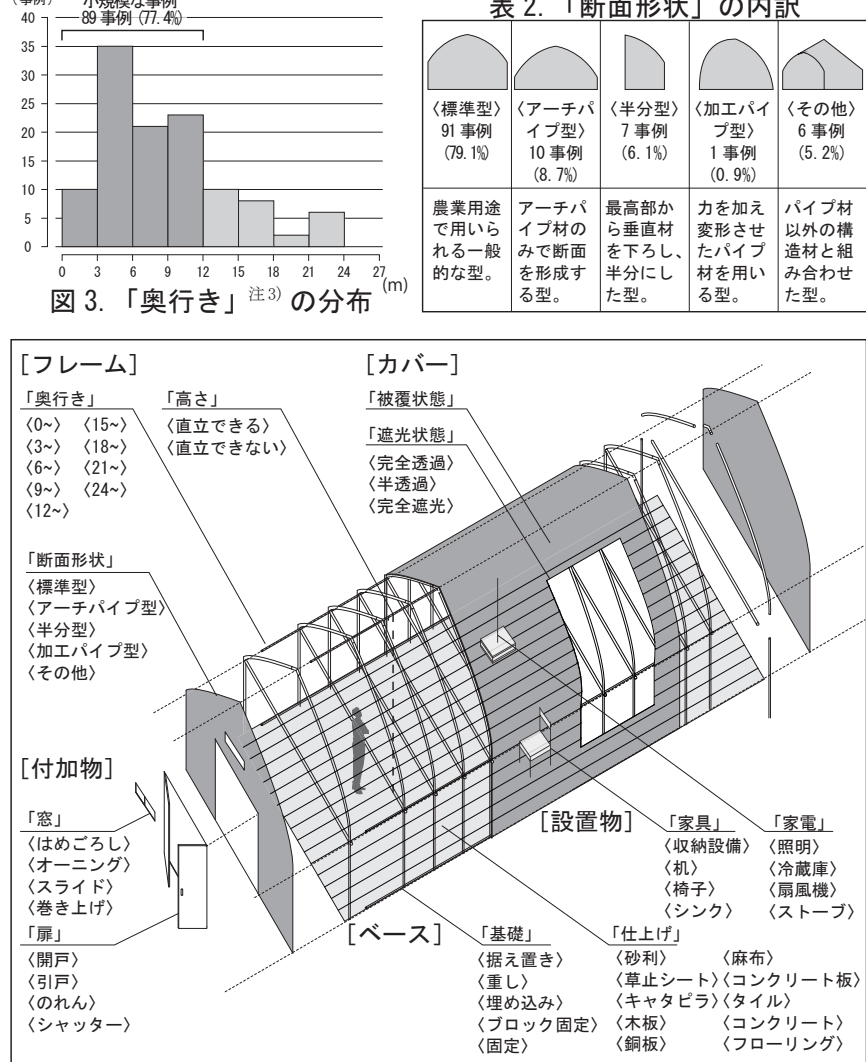

図 4. 用途外 VH の構成要素
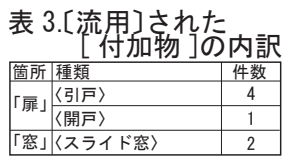

表 4.[造作]された

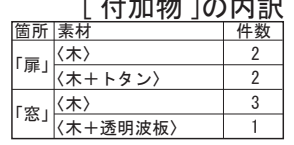

表 5. 新規 [カバー ] 素材 表 6.「仕上げ」の内訳

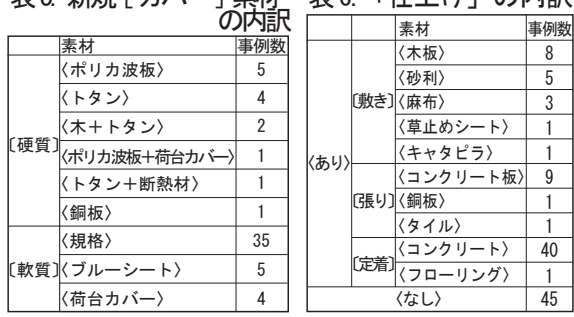

表 7. [ 付加物 ] の内訳 (「扉」「「公」) 注 4 )

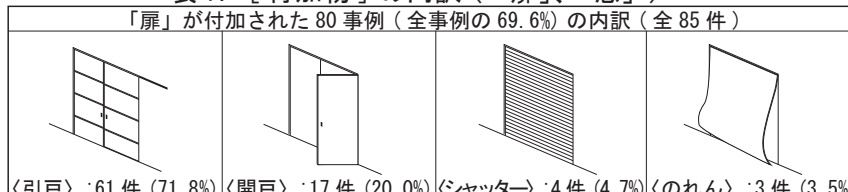

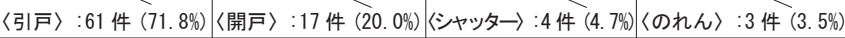

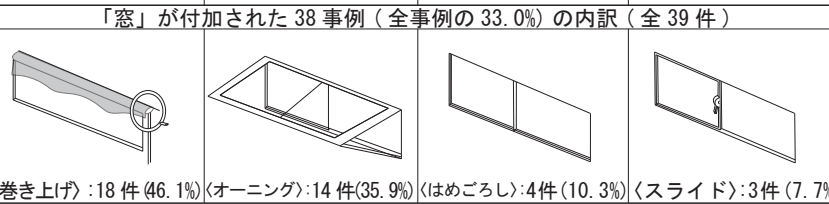

〈巻き上げ〉:18 件 $(46.1 \%)\langle$ オーニング〉:14 件(35.9\%) 〈はめこころし〉:4件 $(10.3 \%)\langle$ 〈スライド〉:3件 $(7.7 \%)$

表 8. [ 設置物 ] の内訳注 5)

\begin{tabular}{|c|c|c|c|c|c|c|c|c|c|c|c|c|c|}
\hline \multicolumn{10}{|c|}{ 「家具」が設置された 40 事例 (全事例の $34.8 \%$ ) の内訳 (全 84 件) } & \multicolumn{4}{|c|}{$\begin{array}{l}\text { 「家電」が設置された } 16 \text { 事 (例 } \\
\text { (全事例の) } 13 \% \text { ) の内訳 (全 } 20 \text { 件) }\end{array}$} \\
\hline 〈椅子〉 & : 33 件 & $(39.3 \%)$ & 〈収納設 & 備〉:32件 & 牛 $(38.1 \%)$ & $\langle$ 机〉 & :17 件 (2 & $(20.2 \%)$ & 〈シンク〉| & 〈照明〉 & 〈扇風機〉 & $\mid\langle ᄌ R-\rightarrow\rangle$ & |冷蔵庫 \\
\hline [既製] & [転用] & [造作] & 〔既製〕 & [転用] & [造作 ] & [既製] & [転用] & [造作] & & & & & \\
\hline 20 件 & 9 件 & 4 件 & 12 件 & 2 件 & 18 件 & 9 件 & 0 件 & 8 件 & (2.4\%) & $(60.0 \%)$ & (15. 0 & $(15$. & (10. \\
\hline
\end{tabular}

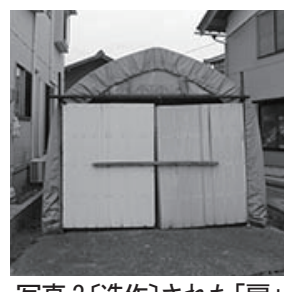

表 9.「基礎」の内訳

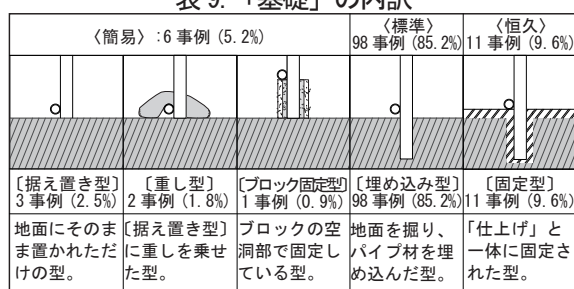


状況によって検証した。床面の「仕上げ」を見ると、仕上げが施さ れた〈あり〉が 70 事例 (60.9\%) で、特に手を加えていない〈なし〉 が 45 事例（39.1\%）であった（表 6)。さらに〈あり〉の事例を詳し く見ると、〈コンクリート〉が 40 事例 $(34.8 \%)$ で最も多く、次いでくコ ンクリート板〉が 9 事例 (7.8\%)、〈木板〉が 8 事例 (7.0\%)であった。 用途外 VH の設置では既存地面の保持が優先され、また利用者にと って入手や施工の容易な素材が選ばれていると考えられる。

\section{5-3. 付加のされ方 / 家屋内的環境を指向}

用途外 VH の付加のされ方を、外装への [ 付加物 ]、内部への [ 設置物］によって検証した。［付加物］に関しては、内部での活動 が多様化したことによって、入口に「扉」を取り付けた事例が 80 事例 (69.6\%)、開口部に「空」を取り付けた事例が 38 事例 (33.0\%) で確認された（表 7)。さらに「扉」の形状は〈引戸〉が 61 件 (71. 8\%) で農業用 VH の既製品をそのまま使用しているものがほと んどであるが、中には〔造作〕されたものもあった（写真 3)。ま た [設置物］に関しては〈椅子〉が 33 件 (39.3\%) で最も多く、次 いで〈收納設備〉が 32 件（38.1\%）であった（表 8)。積極的に部材 や設備が付け加えられていることから、用途外 VH の内部において、 住居内と同様の行為が可能な環境が指向されていると考えられる。

\section{5-4. 仮設性 / 恒常的な上屋と暫定的な基部}

用途外 VH の仮設性を、[ベース］、[カバー］の設えがどのくら い暫定的かによって検証した。[ベース］の「基䃈」を見ると、パ イプを埋め込む〈標準〉が 98 事例 $(85.2 \%)$ で最も多く、また、よ り仮設的な形状の〈簡易〉が 6 事例 (5.2\%) であった（表 9)。この ように基部は暫定的な一方で、[カバー］の「被覆状態」を見ると、 全て被覆された〈両妻面全面〉が 82 事例 $(71.3 \%)$ で最も多く、被 覆が少なく仮設的な事例は 7 事例 (6.1\%) と少数であった（表 10)。 上屋とは異なり基部は恒常性より仮設性が優先され、開発や整備な どに合わせた変更が容易な形態に留められていると考えられる。

\section{$5-5$. 独立性 / 開放的な利用}

用途外 VH の独立性を、[カバー］の被覆状態や視線の透過状態 によって検証した。全ての面が被覆された〈両妻面全面〉の 82 事 例のうち、内部が視認可能から゙うかを「遮光状態」で比べると、63 事例 $(76.8 \%)$ が視認可能であった（図 5)。用途外 VH は、農業用 $\mathrm{VH}$ と同様に空間は覆われているものの内部が視認可能な状態で使 用されており、開放的に利用されていることが分かる。

以上から、用途外 VH の上屋は開放的であり内部に対して特に手 が加えられていることが分かった。基部では仮設性が優先されてお り、設置地面は原状が保持されていると言える。また、形態は周辺 の環境や敷地状況に応じて変更されていると考えられる。これらの 特徵をもとに《改造度》、《既存活用度》、《付加度》、《仮設度》、《独 立度》の 5 つの形態指標を設定し（表 11）、用途外 VH の形態的特 徵を考察する。なお度数の算出に際しては、形態指標毎に設定した 項目のうち該当した項目数を指標における度数とした（表 12）。

\section{6.【形態】と【立地】の関係/市街地と農地の混在}

算出した $5 つ の$ 形態指標を基に、立地との相関を見た。立地毎の 《仮設度》に着目すると、[農地］に比べ［宅地］の方が高い（図 6)。 家屋付近の用途外 VH は、開発や整備による住環境の変化に対して、 応急的に作られていると考えられる。また、立地毎に「遮光状態」
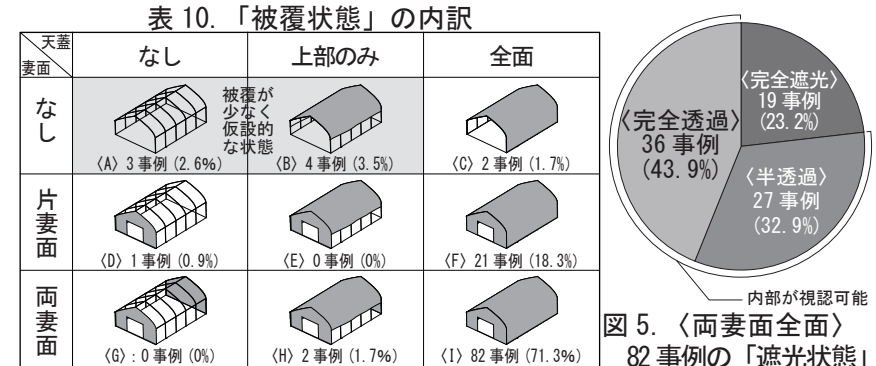

図 5. 〈両妻面全面〉

表 11.5 つの形態指標

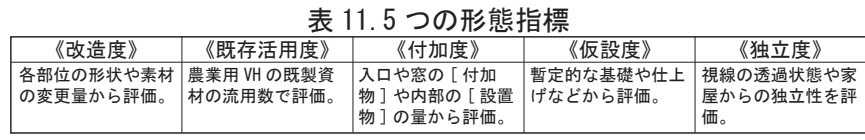

表 12.5 つの形態指標の評価項目

度数の算出方法: 該当項目 1 点につき 1 ポイントを加算

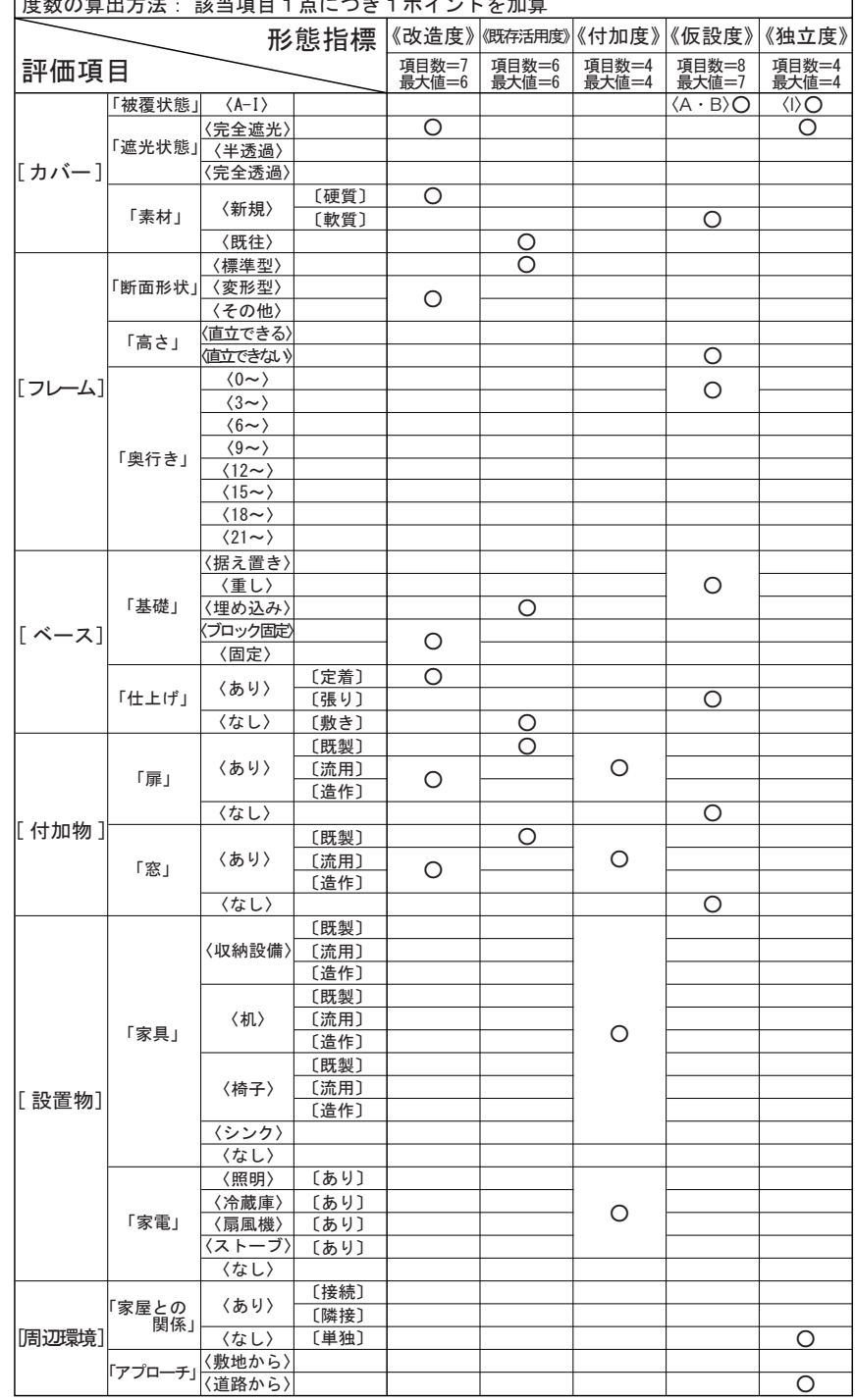

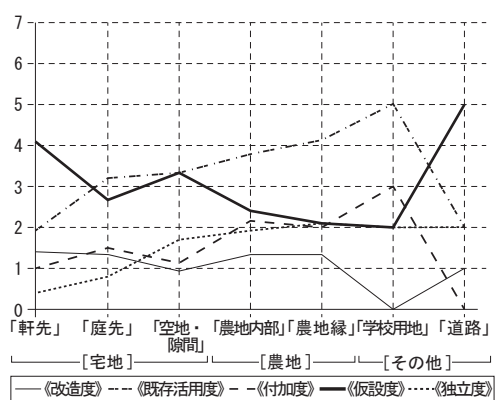

図 6. 立地毎の形態指標

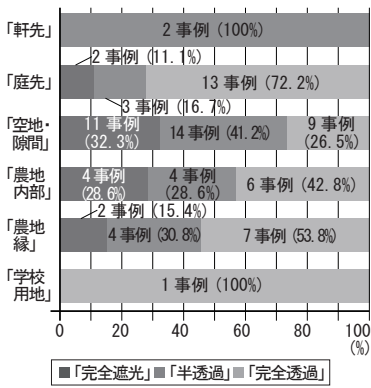

図 7.立地毎の「遮光状態」 
の内訳を見ると、隣家や周辺道路の付近にあり周囲からの視線が 特に懸念される「空地・隙間」では、〈完全遮光〉の占める割合は $32.3 \%$ (11 事例) で他の立地と比べ大きく、〈完全透過〉は26.5\%(9 事例 ）と他の立地と比べ小さい。周辺からの視線が懸念される場合 には、内部が見えないように加工が施されていると推察される。市 街化農地に設置される用途外VH の形態は、特に周辺の環境や敷地 状況に応じて変更されており、農地に住居が混在する市街化農地の 状況を反映したものとなっている。

\section{7.【用途】と【立地】から見た【形態】/市街地化の段階を反映}

用途と立地のマトリクス（表 13）から、特に事例が多く見られた 5 つの組み合わせにおいて形態的特徴の傾向を見た（表 14）。［農地］ における [滞在 ] 用途では《改造度》が高く、住居から離れた場所 での收容物の保護を目的として、堅牢に作られていることが伺える。 次に詳細な項目の組み合わせを見ると、立地毎で「作業場」の形態 的特徵に差異が見られた（表 15）。[宅地］に比べ、[農地］の「作 業場」は《付加度》が高く、用途外 VH が住居内で使用するには古 いが、まだ使用できる物の活用の場となっていると言える。続いて [宅地]内の場所毎でも、「倉庫」の形態的特徴に差異が見られた（表 16)。「軒先」や「庭先」では《改造度》が高く、盗難防止や保護が 必要な物が収容されていることが伺える。家屋の付近にある事例と は逆に、「空地・隙間」では内部収容物の保護よりも仮設性が優先 されている。以上から、用途外VH は、休耕地や空地などの市街化 農地にある余剩敷地において、これまで住居内にあった物の活用や 暫定的な収容のための場として利用されていると言える。こうした 応急的な用途外 VH が散見される地域は、利用者の新たな要求の表 出が伺えることから、市街地化する初期の段階であると推察される。

表 13. 用途と立地のマトリクスにおける事例数の分布

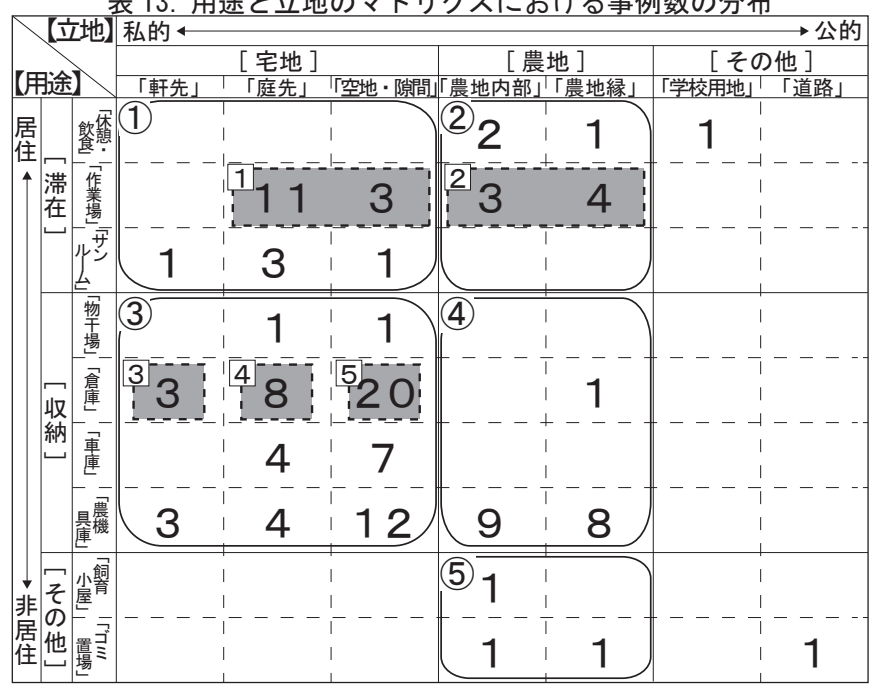

表 14. 用途と立地から見た形態的特徵

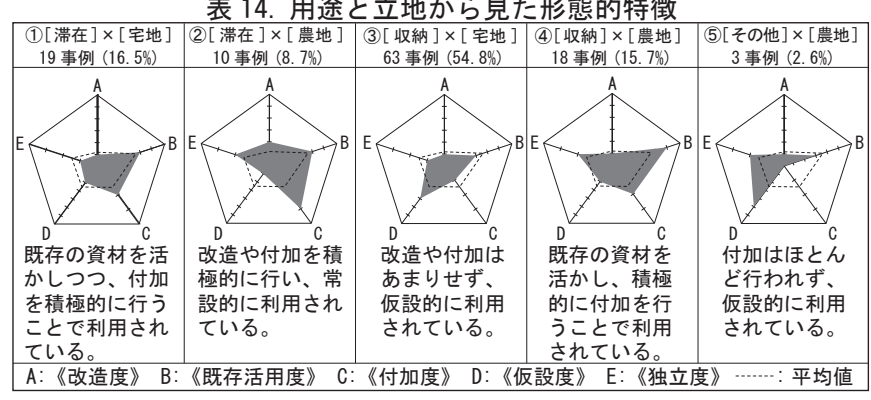

表 15. [ 宅地 ] と [ 農地 ] による「作業場」の比較

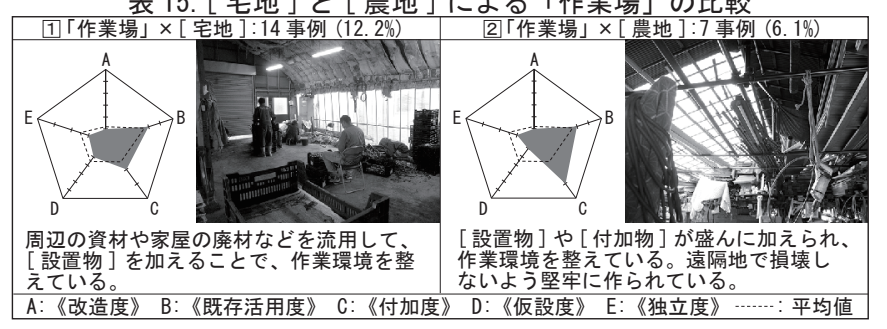

え:《改造度》

\begin{tabular}{|c|c|c|}
\hline $\begin{array}{c}3 \text { 「倉庫」 } \times \text { 「軒先」 } \\
3 \text { 事例 }(2.6 \%)\end{array}$ & $\begin{array}{c}4 \text { (倉庫」 } \times \text { 「庭先」 } \\
8 \text { 事例 }(7.0 \%)\end{array}$ & $\begin{array}{c}5 \text { 「倉庫」 } \times \text { 「空地・隙間」 } \\
20 \text { 事例 }(17.4 \%)\end{array}$ \\
\hline 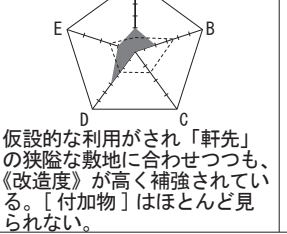 & 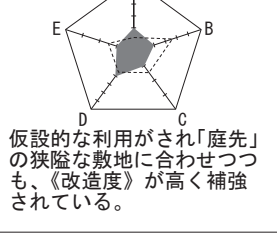 & 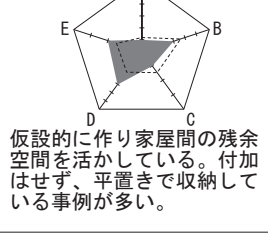 \\
\hline$\langle 己 2$ & 度》 $\mathrm{D}$ ：《仮設度》 & $E$ :《独立度》 \\
\hline
\end{tabular}

8. まとめ/用途外 VHによる市街地化の把握

用途外 VH は、居住から非居住まで様々な用途を必要に応じて簡 便に提供することで、市街地と農地の関係を調節する役割を担って いる。また、住宅地や住居内への設置が忌避される用途を生活空間 とは隔たりを持った VH 内に収めることで、住居を補完する役割を 担っている。用途外 VH は上屋自体よりも内部に対して特に手が加 えられ、基部では仮設性が優先されている。また、用途外 VH はそ の形態が、周辺の環境や敷地状況に応じて変更されていることから、 設置されている地域における住環境や個人の要求などの現状を反映 していることが分かった。市街化農地では、農村地域と市街地化さ れた地域は無秩序に混在しており、住環境に変化が求められている。 また、市街地化における初期の段階では、用途外 VH の仮設的な設 置や住居内で使用していたものの活用などによって、住環境の変化 に応急的に対応していると言える。用途外VH は、市街地と農地の 関係を調節する役割を担うことで、市街地と農地が混在した特徴的 な地域の形成の一助となっていると言える。用途外 VH は、今後の 市街地化の変化にも個人レベルで対応できる可能性があり、市街地 化による住環境の変化を緩やかにすることができると推察される。 地域におけるニーズをより詳細に把握するために、用途外 VH の自 力建設という側面に注目し、所有者が農家かどうかや自作の程度な どについて調查・分析していくことが今後の課題として挙げられる。

\section{参考文献}

1) 梅川元一, 大倉健, 貝島桃代, 岩田祐佳梨 : 焼畑農業から茶業の発展期 にみられる付属小屋生業の变遷からみる茶農家における付属小屋 本川根町小山集落を事例として一 (1)，日本建築学会大会学術講演梗 概集 F2, pp. 185 -pp. 186,2013

2) 黑坂貴裕, 安藤邦廣: 茨城県におけるタバコ乾燥小屋の構法と成立過程 農家の付属小屋に関する研究 その 1 , 日本建築学会大会学術講演梗 概集 E1, pp. 707-pp. 708, 2000

注

注 1）観察記録では適宜利用者への聞き取りを行ったが、期間内に聞き取りの できた利用者数が少数であった為、分析では補足的にのみ用いた

注 2) 用途外 $V H$ としての耐用年数や所有者の要求の変遷を知る上で、時間軸 の観点からみた分析が必要であるが、目視では正確な建設時期が判別で きないことから省略した。

注3)「奥行き」は事例毎のアーチ間隔数に、農業用 VHの標準的なアーチ間 隔である $450 \mathrm{~mm}$ を掛けることによって算出した。

注4) ひとつの事例に対して、複数取り付けられている「扉」が 5 件、「空」 が 1 件あったため、各件数の総和は事例数を超えている。総件数は、「屝」 は 85 件、「空」は 39 件となった。

注5) ひとつの事例に対して、複数取り付けられている「家具」が 44 件、「家 電」が 4 件あったため、各件数の総和は事例数を超えている。総件数は、 「家具」は 84 件、「家電」は 20 件となった。

[2015 年 5 月 25 日原稿受理 2015 年 7 月 27 日採用決定］ 